\title{
ISLAM IN THE JAVANESE CULTURAL PLURALISM AND THE KERATON PERFORMING ARTS
}

\author{
K.R.T. Sunaryadi Maharsiworo \\ Indonesia Arts Institute, Yogyakarta
}

\begin{abstract}
The religion of Islam as new religion in the $15^{\text {th }}$ century managed to internalize in the religious and cultural field of Javanese society peacefully. The religion was easily accepted because all its teachings are based on a search of "sangkan paraning dumadi" and promote "Manunggaling kawula lan Gusti" as in principles of the Javanese human life. The concept of kewalian, the mysticism and the concept of perfection of life could be applied in the formulation of the Keraton (Javanese Sultan's Palace) which became a model of the traditional conception of a variety of social rules and rituals, so that there is mutual interdependence between the Islamic teachings and the community who are still bound by tradition and customary norms. Then various rituals that have been Islamized emerged. Islam was conceived and developed with the Javanese view, absorbed and processed into different forms of Kejawen (Javanese) culture different from the original form, and acceptable to society. In the world of performing arts, needless to say, it has been affected by subculture of Javanese Islam. At least such impressions can be seen in the wayang (Javanese traditional puppetry) performance and ritual dances such as bedaya, wayang wong,or Golek Menak in the Keraton of Yogyakarta.
\end{abstract}

Keywords: Islam, cultural contact, Javanese Philosophy, Dance

\section{INTRODUCTION}

The coming of Islam to Java has so far become an unfinished debate. How Islam came to the Indonesian Archipelago is still questionable as no authentic evidence can be accounted for. Several historical sources explain that Islam came from two different places; one from Southern India and the other from Northern India. Southern India, particularly the region of Kerala was the harbor for traders from Sumatra, Malaysia, China, and the resellers of pepper trade relations between Arabia, India, Southeast Asia, and China. The Kerala Islam was influenced by the Arab traditions and embraced by scholars along the northern coast of Java, while Northern India (Deccan) was dominated by religious and political systems of Indo-Persian (Mark R. Woodward, 1999: $81)$.

This fact is supported by the description in the document of Babad Tanah 
Jawi, Babad Gresik, Hikayat Hasanudin, and Serat Kandaning Ringgit Purwo regarding the existence of the relationship of marriage between the Kingdom of Campa which had embraced Islam with the Majapahit Kingdom, as well as a sign of the emergence of Islam among the Royal family around the $14^{\text {th }}$ century. The evidence is clear that enculturation of Islam in the Javanese society is a continuous process which is mutually giving and accepting, or critical reciprocity (Marcel Mauss, 1952: 12-17) between the values of Islam and those of Javanese society. Some of the changes caused by the mixture have, in fact, enriched both the Islamic religion and the Javanese culture. As a process (which is still in progress), the transformation of culture also reflects a dialectic between the adjustment and incompatibility, acceptance and rejection on a broad background as Islam was trying to enter the gate of Javanese culture, from the coastal areas to the far inland (M. Ricklefs, 1993).

\section{THE ROLE OF RELIGION IN THE SPREAD OF CULTURE}

Long before Islam came, the people of Indonesia or the people of Java had practiced beliefs related to ancestral spirits or souls contained in objects, plants, animals or human beings. Objects, plants or animals are thought to have supernatural powers or spirit, be it evil or good. Thus the relationship between humans, animals and plants becomes very close. All forms of beliefs affect human behavior especially in facing the difficulties of life. Natural disasters or disease outbreaks are often associated with the rage of spirits or the various imbalanced forces in natural objects. The anger of many of the spirits and the imbalanced forces in natural objects will end if people approach them by giving offerings or holding ceremonies accompanied by dances and sounds that are intended to provide a mystical atmosphere to spirits or supernatural powers from which help is expected to be present in the ceremony. The Javanese community believes that the forces of nature are one of the deciding factors in their lives. Agricultural success depends very much the forces of nature, the sun, rain, and wind although they also believe that there are supernatural forces behind all those powers.

When the Hindu religion came to the Indonesian archipelago, the preHindu beliefs did not experience the significant turmoil, since they shared some similarities. Hinduism is also loaded with various ceremonies to gain prosperity. The pre-Hindu beliefs depend on the spirits of ancestors and forces of nature or the unseen while the harmony of the cosmos in Hinduism is reached by getting closer to the help of the gods. The Hindu communities also recognize the rituals of fertility, believing in the eternal spirits of the ancestors (through understanding of moksa), as well as the spirits of good and evil, a 
circle of suffering (samsara), and the law of karma.

With respect to the belief, in the teachings of Buddhism also recognize the four kasunyatan (truths), namely dukha (suffering), samudaya (cause of suffering), nirodha (controlling one's desire), and marga or the release into Nirvana (Abdul Jamil, 2000: 124). It means in some respects the nature of the teachings of both Hinduism and Buddhism fits the religious heritage of the native peoples of Indonesia, so as to facilitate the smooth process of acculturation between cultures that have developed in the community and those of Hinduism and Buddhism. The religious beliefs of Hinduism, Buddhism, and animism as well as all the dynamism in the process of the development of Islam inter-relate with Islamic beliefs.

There are two issues that need to be kept in mind with respect to the arrival of Islam in Java. First, the existence of Hinduism, Buddhism, and the old beliefs that had rooted and grown in the society long before Islam came. When Hinduism and Buddhism began to flourish, the Javanese culture did not dissolve into the two religious beliefs, but on the contrary the two cultural elements were "Javanized" thus the term Hindu-Javanese culture appeared, because the religious-magic values of Hinduism and Buddhism were in line with the pre- Hindu animistic- dynamistic cultural values. While Hinduism and Buddhism thrived among the elites of the Keraton, the traditional beliefs which are based on animism are pervasive among the commoners. Although the three faiths have different teachings, they all share one point of destination. All of them are rich with mysticism and aimed at finding sangkan paraning dumadi (genesis) and manunggaling kawula gusti (union with God).

Second, the exact period of the coming of Islam to Java is still disputed. The massive Islamization occurred in the $15^{\text {th }}$ and $16^{\text {th }}$ century marked by the fall of Hindu-Javanese Majapahit (1478) and the establishment of the first Islamic Kingdom of Demak. The massive Islamization in Java thus occurred at a time when the Muslim world suffered a setback in many ways. In the year 1000 there were a lot of setbacks in the field of thought and science, so the practice of Sufism, the mysticism, tarekat. Therefore, Islam that came to Java at that time was filled with mysticism.

Since mysticism was commonly found among the Javanese, the task of the mubaligh (Islamic proselytizers) called Wali Songo (Nine Guardians/Saints) to spread Islam was easier. The Walis were tolerant and open in facing different views related to local cultural traditions. They kept the Javanese traditions alive by giving the nuances of Islam to the traditions such as Sesaji (ceremonial offerings for the worship of spirits and gods) which was replaced with the tradition of kenduri or selametan (communal feast). Giving kenduri 
to the neighbors will create harmony between them which corresponds to the Islamic teachings. Previously, sesaji was accompanied by spells and Sunan Kalijaga replaced it with slametan which was then accompanied by khalimah thoyibah. Sunan Kalijaga was known for using methods which were not against culture but instead filling it with the teachings of Islam, and based on deliberation.

The Walis also proselytized through cultural and artistic approach. Sunan Giri (Raden Paku) wrote Asmaradana and Pocung songs, and taught religion to children through games as well as spreading Islam in Sulawesi and Sunda Kecil. Sunan Kalijaga wrote the song Dandanggula, created the puppet play with the Islamic message as well as puppet props made of leather such as kelir (as a symbol of the universe), debog (earth), blencong (symbol of the Sun), puppet master to play the puppets. Meanwhile, Sunan Bonang (Mahdum Ibrahim, son of Sunan Ampel) who served on the northern coast of East Java, wrote the song Durma. He also attempted to change the names of the gods with Islamic names. Sunan Kudus, whose area of operation included the coast of Central Java, wrote the songs Maskumambang and Mijil as well as fairy tales about Islam. Sunan Drajat, a philanthropist who helped orphaned children and sick people, also composed the song Pangkur.

Sunan Muria was popular among fishermen and merchants. He wrote the songs Sino and Kinanti, and preserved the gamelan (traditional musical ensemble), as well as gendhing-gendhing which contains the teachings of Islam. Sunan Gunungjati (Syarif Hidayatullah) or Fatahilah or Faletehan incorporated Islamic elements into praises, $d z i k i r$, and prayers (Karkono Karnajaya Partokusumo, 1995: 291-294). The Walis also wrote some of the puppet plays which contain the message of Islam such as Dewa Ruci, Jimat Kalimasada, Jaya Pusaka, Bagawan Ciptoning, Petruk dadi Ratu, Pandu Pragolo, Semar Mbarang Jantur, Bale Sigolo-golo, Wahyu Widayat, dan Kresna gugah (Ridin Sofwan, et al., 2000:157-158)

In the economic field, Sunan Kalijaga contributed through his work related to agriculture through the philosophy of bajak dan cangkul (plow and hoe) in his book called Cupu Manik Astagina. The plow and hoe is made up of several sections as follows:

1. Pegangan, meaning that to achieve the goals of life, one should have firm life principles and enough experience.

2. Pancatan, if the principles already exist, one should act soon.

3. Tanding, meaning that before acting, one should make comparison as to which action to take.

4. Singkal (metu saka ing akal) after making consideration and doing research, 
one will get a sense or way to achieve the expected results.

5. Kejen (kasawijen), the unity between the energy and mind.

6. Olang-aling, having achieved the unity of energy and mind, then there will be no obstacles.

7. Racuk (ngarah ing cucuk), if we pursue the ideals and act according to the instructions above, we will definitely reach our dreams.

The plow and hoe philosophy served a medium of education on philosophy and preaching among the community at the time. The Walis also taught that occupations related to trade, agriculture and carpentry were not a low status as defined in Hinduism regarding human categorization in castes (Brahman for religious leaders, Kshatriya for the nobles, Vaisya for the merchants, artisans, farmers, and Sudra for the workers/porters or landless peasants). In addition to being religious figures, the Walis also made their living as merchants. Thus, they indirectly enforced the egalitarian views among the Javanese society and eliminated the differences.

To avoid conflict in the community, the development of Islamic propagation in the field of education was conducted through establishing pesantren (Islamic boarding schools) which took the form of education originally taught the monks and clergy. The Pesantren is a continuation and modification of Hindu institution, the Mandala. Various terms related to Hindu, Buddhist rituals are still used today, such as the term sembahyang (worship) which is used to refer to salat (prayer). For places of worship, the term used is langgar, a similar term for sanggar which is a temple. The students are called a santri, derived from the word shastri in Hindi meaning one who studies the holy books. The boarding school system which was a pre-Islamic cultural transformation was for the first time developed by Syekh Maulana Ibrahim in Gresik.

Apparently the spread of Islam in Java was done through the Islamization of the Java culture on the one hand, and Javanization of Islam on the other. The Islamization of Culture is an attempt to preserve an existing Javanese-style Islam, either formally or substantially. As mentioned above, these efforts were conducted through using the Islamic terms and names, telling about the role of historical Islam figures, as well as applying of the law and the norms of Islam in various aspects of life. The Javanization of Islam is defined as the internalization of the Islamic values into the Javanese culture by maintaining the use of Javanese names and terms. Acculturation and syncretization occurred between local traditions and beliefs with the Islamic teachings and culture. In this acculturation, Islam has influenced the local traditions and beliefs, and similarly the local traditions have also affected the implementation of the Islamic teachings. As a result, there are a lot of original Javanese rituals 
that have Islamized such as ceremonies of surtanah, nelung ndina, mitung ndina, matang puluh ndina, nyatus, mendhak, nyewu and so on. An attempt to accommodate the Islamic values and the local cultures can be seen here, although in some respects, the pre-Islamic cultural heritage is still evident. Islam that entered Indonesia (Java) was that which has been combined with the Persian and Indian mysticism. The Javanese mystical and philosophical world is the link which facilitated the inclusion of the elements of Islamic cultures in Javanese people's daily lives. In this case the Javanese historiography assumes that all events have mystical and religious reasons. Therefore religion is a political power and the legitimacy of the Keraton.

\section{FROM POWER TO CULTURAL VALUE OF KEJAWEN}

The spread of Islam into the interior part of Java has caused the Keraton Javanese culture which is oriented toward political values to be confronted with the Islamic culture that focuses on the Shariah. The result of the differences sometimes may cause a tension to become an open conflict. This occurred during the Mataram Kingdom which was ruled by Senopati. Mataram was a representation of the Javanese community that had agrarian cultural roots. In the context of culture, agricultural societies are static and often place power as a central theme in life. In the political dimension, all the political aspects tend to be a tool of power. It was also the case in the process of acculturation between Javanese-Hinduism-Buddhism and Islam. The difference of concept between Mataram and the relatively dynamic and open coastal Islamic community led to the emergence of conflict with the coastal regions.

Sultan Agung, Senopati's successor, realized that the condition would undermine Mataram. Therefore, he was trying to build a cultural strategy in order to maintain power, taking the coastal Islamic culture to be synthesized with the Javanese inland culture, which is then referred to as JavaneseIslamic culture or Kejawen, with the goal of keeping a socio-cultural stability throughout the territory of the Keraton. When the Islamic coastal power represented by the Giri region was defeated by the ruler of Mataram, there appeared a combination of Javanese culture called Kejawen Islam. Regarding the process of transformation, the culture strategies adopted the rulers of the Kingdom when dealing with Islam can only be understood from the way of power mythicism (R. Von Heine-Geldern, 1956: 14-18), as seen in the use of the term "khalifatullah sayidin panatagama" for the title of the ruler of the Mataram Kingdom. The title of a King, in addition to having earthly powers, also serves as a religious leader.

There was similar concept between the period of Hindu-Buddhism and that 
of Islam. During the period Hindu-Buddhism, the legitimacy of a monarch was approved by the understanding that the ruler was a representative of god. During the Islamic period, a ruler (king) was trying to find the level of 'godking by styling himself as the khalifatullah (representative of Allah). The King of Yogyakarta carries the title of Sultan in the sense of unity as "Ngarsodalem Sampeyandalem Ingkang Sinuwun Kanjeng Sultan hamengkubuwana, Senopati Ing Ngalaga Ngabdurachman Sayidin Panagama Khalifatullah Ingkang Jumeneng kaping...." The title of the Sultan is a practice of ngarsodalem or one that stays in front of sampeyandalem (your feet). The two words contain the notion that in life every person has to step forward. Ingkang sinuwun or the expected that kanjeng sultan (a will to uphold justice), Hamengku Buwana means protecting the world (martyr) for all the people, thus achieving unity between kawula and Gusti.

The Javanese ideas of manunggaling kawula Gusti are basically the teachings of Kejawen Islamic Sufism (mysticism), which had evolved in the $17^{\text {th }}$ and $18^{\text {th }}$ century, and became the Mataram Kingdom's political system. Manunggaling kawula Gusti has a concrete meaning of the unity of people with the King. The core of this idea, in addition to a notion of unity, also means balance. Balance between physical and mental state, between faith and charity, between science and ethics, between ability and willingness, in an introspective way. With such concept, the King as God's representative in the world is the chosen one who is born to lead the world.

Javanese or Kejawen Islam is indeed a unique phenomenon. Not only is it able to maintain cultural and religious aspects of the pre-Islamic era, but it is also due to the concepts of kewalian (saintdom), mysticism, and perfection of human life applied in the cult of the Kingdom. The Keraton Cult here is an attempt to unify various Muslim traditions by implementing the interdependence between the teachings, rituals and social life. So Javanese Islam is not simply a replica of the Middle Eastern or South Asian Islam, but it is a picture of an intellectual and spiritual traditions of the dynamic and creative Muslim world. It can be said that Kejawen Islam is the Islam teachings understood and developed in the framework of the Javanese tradition. Although not so solid as the Santri Islam, Kejawen Islam is credited as an introduction for the culture lovers to get to know the teachings of Islam.

\section{ISLAM AND THE PERFORMING ARTS KERATON}

According to Soemarsaid Moertono, the theory of the Javanese kingdom is based on a "splendor cult" which leads to the equation between the theory of kingdoms and kewalian and Sufic doctrine of unity with mysticism. Officially, 
the Javanese Keratons embrace Islam, though their lifestyle has been heavily influenced by the Javanese-Hindu traditions. The King has a strong mystical power so he can marry Ratu Kidul, the sovereign of the South Sea who is an important figure in the Javanese tradition. Ratu Kidul has become the focus of Royal Javanese rituals to maintain balance in the cosmos, since the imbalance between the Cosmos will lead to the destruction of the country. It is also the case with the architecture of the Kraton (Yogyakarta) built by Sultan Hamengku Buwana I is a miniature model of the Javanese dance of Sufic theory regarding the description of the structure of the Cosmos on human nature, his relationship with God, the origin of his existence, as well as his final fate. The symbolism and architecture of the Keraton describes the Islamic structure of the cosmos, the relationship between Sufism and Shariah, the cosmological and introspective outline of the mystical path. All of it is elaborated in the human face symbolizing the path from birth to the consummation of life which is reflected in the philosophy of the existence of a building next to the Keraton called Krapyak and a monument in the north side.

If examined from south to north of the Yogyakarta Keraton, it depicts a human journey since his time in barzah where he receives his soul, then takes the form of a sperm, an embryo and becomes an adult with a variety of obstacles that must be faced in order to achieve happiness. If examined from north to south, the Keraton represents a man's journey toward the end (death) to achieve eternal perfection i.e. unification with God which is known in Javanese philosophy as manunggaling kawula Gusti. The Keraton serves the Kingdom's centre of administration with the main attention on the concept of loyalty and duty, a similar sense of worship to God. The Keraton and the central courtyard of the Keraton is the symbol of climbing a ladder to heaven to come to the unity of the divine.

This concept of manunggaling kawula Gusti is made clear by the presence of Tugu Golong-Gilig in the northern side of the Keraton, with its rounded shape like golong rice sustained by cylinders (gilig). There are two meanings implied here, kawula could mean people and Gusti means King, but the kawula could also be interpreted as a King while Gusti is his God. The harmony of relations between humans, King (leader), and God is the goal of the Javanese human life. In the religious and philosophical conceptions of the Javanese Kingdom, the Keraton is a microcosm of the order of the visible universe (world). The parallels between the macrocosm (jagad gedhe) and microcosm (jagad cilik) depend on the success of humans in creating harmony of life by following the existing symbols. In this concept, the main duty of a King is to maintain sustainability of harmony between the Kingdom and the universe. 
By studying the meanings of the various Javanese traditions, it is clear that the issue of Islam in Java is not how to incorporate elements of Islam into the Javanese culture, but how to reinterpret the existing symbols of HinduBuddhism using the Islamic concept. The Keraton has also become a center of classical Javanese culture with its dances, puppetry and gamelan (traditional musical ensemble), as well as various religious rituals held in the early days of Islam. Prince Mangkubumi (Hamengku Buwono I), the founder of the Kraton, was one who qualified in all areas. In the field of performing arts, Sultan Hamengku Buwono I created a variety of dance forms such as Beksan Lawung, Beksan Guntur Segara, Beksan Sekar Medura, Wayang Wong, Beksan Tameng, Lelangen Beksa Bedhaya. In the political concept of the Javanese Kingdom, it is recognized that the king is the ruler that has the foundation of the incarnation of god (god-king). In this case bedhaya serves as a symbol of Shiva, so its existence becomes an inseparable unity with the king. The concept of god-king that originated from the Hindu era is still recognized in the Islamis period in form of khalifatullah or the representative of Allah. In Serat Wulangreh it is also said that Ratu kinarya is wakil Hyang Agung (representative of Allah). However, keep in mind that the notion of the position or power of the king (leader) will be of benefit to the wider community and bring people's welfare if accompanied by the awareness that a ruler should be ambeg adil paramarta, berbudi bawa laksana, and wicaksana. It means that the power should be based on fairness, thoughtfulness demeanor, and wisdom. Understanding of the concept of leadership as a whole is now quite often forgotten, so people sometimes tend to abuse power.

The ideals of unity between "oneself" (human) and the Divine are for humans to achieve kawruh "sangkan paraning dumadi" i.e. kawruh (knowledge) about the origin (sangkan) of his existence and purpose in building the harmony of life. The harmony between the word, hearing, eyesight, thoughts and feelings in establishing a balance between passion and reason aims to defeat the bad and to reach the happiness of the world and the hereafter. The changes of the positions in the bedhaya dance, which are often made by the dancers, are a picture of imbalance that frequently occurs between the will and the logic. The conflict is described in dynamic motion, yet still looks harmonious in a constant tempo (ajeg), seems to contain the message that not all issues in life must be resolved with violence.

Similarly, the concept of Joged Mataram consists of sawiji (concentration), greged (spirit), sengguh (self-confident), ora mingkuh (firm in principles). The concept it can be manifested in our concentration on something that we are working on that is based on passion, confidence, and act in accordance 
with the teachings of God. Thus this concept can be applied anywhere, not limited to the world of dance, for all the interpretation leads to the teaching of the perfection of life (kasampurnaning urip) and the devotion to others. In addition to the dances performed in the Keraton, the wayang (puppetry), to the Javanese, is a cultural product containing aesthetic, ethical, philosophical and pedagogical values. Therefore, the wayang not only becomes a spectacle, but also serves as a guide to life, a medium of education and dakwah. In short, the wayang is the essence of the Javanese culture. The wayang and the Javanese culture are two inseparable things. This can be seen from the Javanese traditional house which consists of dari emper, pendapa, pringgitan, omah mburi, sentong, longkangan, and pawon.

The wayang is one of the forms of the Hindu cultural heritage that is still preserved to this day. According to Claire Holt in her book Art in Indonesia: Continuities and Change cited by Soedarsono, the wayang performances (in Central Java) have existed since the year 907, as written on a stele built by King Balitung of Ancient Mataram Kingdom. After the Kingdom of Majapahit fell at the beginning of the $16^{\text {th }}$ century, the political power of Javanese culture, under the Islamic kings began to appear in Central Java (1524-1581). It began with the Kingdom of Demak, and was followed by the Kingdoms of Pajang and Mataram. However, the Javanese Islamic kings and the walis still preserved the tradition of wayang which is interpreted with the teachings of Islam. The walis used wayang gamelan and wayang topeng to attract crowds to congregate and listen to sermons.

The wayang world contains the values of the Java of view of life particularly with regard to the attitude and decision that should be made when confronted with an obstacle to truth. In the world of the wayang, life must always be based on truth. Here the moral role is very important, and at this stage the values of Islamic morality are necessary to be included in the wayang. In the literature of Kejawen Islam, a human life is determined by the puppeteer (God) based on the length of time of the show which starts from sunset through sunrise. The middle of the night is depicted as the decisive moment in the life of human beings; the moments in which there is chaos or the turbulence of the Cosmos, and that finally the harmony or peace could only be realized by early morning. In this case the puppeteer as the driving force of the world divides life into three cycles through different styles of play and different gamelan rhythms (Mark R. Woodward: 287-289, Sudarto, 1999: 171). In the gamelan rhythms of pathet nem, the story depicts characters that have not managed to defeat their enemies. This part is a description of the struggle between faith and carnal lust that faced humankind during children up to adults. The second level is on 
tone of pathet sanga, pointing at adulthood. This part includes goro-goro, the scene that begins with the onset of chaos to expel punakawan Semar, Gareng, Petruk, and Bagong who in their joke will see their role as spiritual mentors.

The Hindu epic Ramayana and Mahabharata, there are no any purnakawan character. The emergence of the purnakawan characters was created by the walis to perform a function of the good characters. The names Semar, Nala Gareng, Petruk, and Bagong are derived from Arabic; Semar from Ismar (nail). He is the nail or the safety of the world, like the teachings of Islam spread by the walis. Semar is the aspiration of human physical and spiritual struggle. Physically, Semar represents the spirit that is never faded over time. Spiritually he is interpreted as a creed of faith so that it remains strong in principle. In the Javanese view, Semar who is not as gentle as a warrior is often associated with farmers or the people who represent simplicity. On the other hand, Semar also serves as a manifestation of the Prophet Muhammad which had always served on humanity, and became a mentor to the belief in God. Nala Gareng derived from the word Naala Qoriin means t having a lot of friends. As proselytizers, the walis had to have lot of friends, with whom they will find the wise way to God. Petruk, derived from Fatruk, is a short version of a discourse of mysticism "Fat-ruk-kulla maa siwallahi", meaning "leave anything other than God" (Sudarto: 179-183. Anderson, 1966, Keeler, W., 1987). Bagong derived from Baghaa which means fighting (against falsehood). Bagong also equals baqa 'means lasting. The bottom line is that all beings will experience eternal life in the afterlife. Bagong may also be from the word bahar which means spice. Spice here is a picture of people who are critical, as is the blaka suta. It is obvious that the existence of punakwawan is a form of visualization of the Javanese community, the idea is that human life requires the pamomong figures or people nearby who could lead to the path of God or truth.

The third stage is the pathet manyura, depicting the ksatrias who have managed to conquer the enemy of ther inner desires. When the performances are over, wodden wayang golek appears to keep people/audience nggoleki (finding) the meaning of the show that has just been performed. The end of the show is also marked by the penancapan gunungan as the tree of life in the middle of banana stems that symbolizes a state of silence, with no movement (the end of the show). From the description above, it is clear that the puppet is a medium to teach how people should believe in God and avoid worldly desires that will drive them into a life of hell. In other words, the puppet manifests the nature of truth, ethics, and philosophy, and becomes a full-fledged Javanese man.

The penetration of the puppet as a religious medium that preserves the Javanese traditions is not something easy to do. This is also a problem faced by 
the Javanese kingdoms in building the foundation of strong Islamic traditions in the midst of Hindu Mythology which is already entrenched in the Javanese culture. To bridge the gap between tradition and the teachings of Islam, the transformation is done through the genealogical construction which connects the gods of Hinduism with the lineage of the prophets. Through a series of myths, puppet figures are told as descendants of Adam and Eve, who are the ancestors of all humans. The Hindu charm, Jamus Kalimasada, derives from the words kali maha usada (Hindu), which was later declared to come from the Arabic syahada (witness), which is the beginning of the sentence of recognition of Islam. It means that the statement syahada is the minimum principle to be called a Muslim. The story that becomes a source of guidance for the puppeteer is usually taken from the Serat Mahabarata, Serat Baratayuda written by Yosodipura, Serat Pustaka Raja by Ranggawarsita, or Serat Kandha containing genealogical relationships of the prophets with puppet characters. Meanwhile, Serat Manikmaya describes the process of the interaction between different cultures that exist in Java. As the intersection of Javanese culture and Islam, the walis composed several puppet stories that reflect Islamic values such as Dewa Ruci, Jimat Kalimasada, Jaya Pusaka, Begawan Ciptoning, Petruk dadi Ratu, Pandu Pragolo, Semar Mbarang Jantur, Bale Sigolo-golo, Wahyu Widayat and Kresna gugah.

In its development, in addition to the leather puppet (wayang purwa), wayang gedhog and wayang topeng were also developed. Wayang gedhog is a new development of the wayang kulit performances originated in East Java at the end of the Majapahit era, when Islam began to flourish in the $15^{\text {th }}$ century. The theme is taken from the epic story of Panji. Wayang gedhog later inspired the wayang golek and wayang golek inspired the emergence of beksan golek Menak in the Yogyakarta palace. As in wayang kulit, wayang topenf was also used as a medium of dakwah by the walis. Even in the first performance of wayang topeng in the $16^{\text {th }}$ century, Sunan Kalijaga made nine masks adapted from wayang kulit and wayang gedhog. The nine masks represented the nine characters i.e., Panji, Candrakirana, Gunungsari, Andaga, Raton (King), Klana, Danawa (giant), Renco (Tembem or Doyok), dan Turas (Penthul or Bancak). At the time of Mataram, puppet performances, in addition to being a royal performace, also spread out in the coastal area and the area outside the kingdom (abroad). When the Kingdom of Mataram split into two kingdoms (Kasunanan Surakarta and Yogyakarta Sultanate) in 1755 the mask puppet was still preserved by the Surakarta palace, while Sultan Hamengku Buwono-I did not continue the tradition of the mask puppet, but rather infused the new dramatari (a musical) form of "wayang wong" featuring the story Mahabharata or Ramayana. Wayang topeng flourished in rural communities than in the 
palace.

It was mentioned that in addition to wayang kulit, wayang topeng, and wayang gedhog, in Java especially in the Yogyakarta palace, wayang wong was also developed. The presence of the wayang wong in Yogyakarta was not only as a spectacle or entertainment, but according to Soedarsono, this performance is recognized as an official state ritual performances. Wayang wong in the Yogyakarta Sultanate was also used as a medium of education, as in the play there are religious lessons, the teachings of morals, ethics, life philosophy and principles, state administration. The puppet characters became an example to be imitated or avoided if the character is not good. Another type of puppet that flourish in the Keraton is wayang golek menak, the Arab Persian stories coming into the island through the Malay language, in the form of Amir Hamzah legends. The Amir Hamzah legends in the Persian tradition are the literature of chivalric biography of Hamza Ibn 'Abdul Muttalib (Amir Hamza) mixed with various elements of the Persian people, containing the historical development of Islam from Arabia to Persia. In the text "Menak Persi" it is mentioned that Amir Hamzah plunged into the battlefield to instill Islamic values to the wider community by reading the Qur'an and saying prayers. Story also developed among the society in a populist art form such as Sholawatan (Slawatan), Srandul, and Nod. The forms of folk art are usually displayed on the night of the tirakatan to tingkepan ceremony, circumcision, or marriage. The model of literature development by incorporating elements of local-style with the Keraton is similar to the habit of the Indonesian people in writing books.

In the literary works, serat menak is written in some several versions i.e. Menak Kartasura, Surakarta and Menak Menak-pang (only parts of the whole Menak story). From the form of the literary works, serat menak was composed into the form of art shows such as wayang golek or wayang thengul, which was later composed into several free dances one of which is golek Menak created by Sultan Hamengku Buwana IX shortly after he ascended the throne as the Sultan of Yogyakarta. The Sultan's sons, relatives, and royal guards were required to be able to dance in order to deepen the knowledge about life, and the belief in God. The spread of Islam to Java was followed by the influx of Islamic literature. The spread of this literature, the first Islamic Kingdom of Demak became the medium of a direct connection between the Javanese literature lovers with the walis. The contact generated a kind of literary mix between the tradition /Javanese culture and the Islamic culture that originated from boarding schools (in the coastal areas). Then the Javanese-language books called the Kejawen literature that contains the Islamic values emerged. 
The Keraton manuscripts are mostly expressive literature based on feelings and imagination. In this for of literature, the elements of Islam are tapped and developed.

Serat Menak which originated from Amir Hamzah legends, is among the Islamic-Javanese literature filled with poem-like stories. These stories are distinguished into four types, namely the coastal area version of serat Menak developed in the $17^{\text {th }}$ and $18^{\text {th }}$ centuries, and is regarded as a pure text of Amir Hamzah that was derived from Amir Hamzah legends. Second, the Kartasura Serat Menak was by influenced by the coastal serat menak, but experienced some development. Third, Serat Menak Pang, is taken from parts of the text of Amir Hamzah. Fourth, Serat Menak Surakarta is similar to Serat Menak Kartasura, but its language and psalm have been developed and decorated by Yasadipura so that it belongs the row of baletri literature (beautiful literature). This serat was published into the Indonesian language by Balai Pustaka in 1982. The Serat Menak was then composed into the traditional art of puppetry called wayang thengul or wayang golek. The seriousness of the Sultans of Yogyakarta to disseminate the Islamic religion was manifested by giving the Islamic names to his grand children, such as the names listed in the serta mena: Asimkuari, Marpinjung, Sudarawerti, Sirtupelaeli, Ruslanudanurusamsi, Mukasabiyun, and so on. From the story of golek Menak a dance called golek Menak was developed. Although still limited in scale, the golek Menak dance is a reflection of changes in the powers of the palace towards a more modern outlook on life as a reflection of the changes of the Javanese view on life initiated Sultan Hamengku Buwono IX. The creation of the dance has broken the concept of the Javanese leadership that rests on the grandeur of the god-king or the khalifatullah. The concepts in the bedhaya dance which was sacred for the kingdom of Java was gone with the presence of golek Menak. The Sultan's move was probably based on the realization that Indonesia had entered a new era, a time of national revival towards the state-based people's democracy. Of course as a leader the Sultan also must follow the changes of the era in order for him to exist in the eyes of its people.

Viewed from another angle, acculturation or inculturation shows that the Islamic culture has strengthened the Javanese cultural heritage. The critical interface may have positive or negative impacts. The positive impact is to enrich the Javanese culture so that cultural assimilation occurs peacefully. Conversely, the negative impact is that if the various elements fail to function, cultural diffusion instead of assimilation will emerge, and in a certain context, it shows the meaning of mere inference. It can be observed that the intense participation of the Javanese community to interpret Islam in the context of 
Javanese-Islamic culture can be seen in the various ceremonies that still show the elements of the "encounter" of Islam with the Javanese culture. It can be noticed in various ceremonies such as sekaten, garebeg, and various other traditional ceremonies in the Javanese culture.

\section{CLOSING REMARKS}

In the Javanese culture, pluralism and multiculturalism are the inevitable. That is, both are something that should be there and unavoidable. The complexity of life and interactions with other cultures is the conditions that make up the complexity of the Javanese culture. The efforts to study the complexities of the Javanese culture are interesting because the more deeply it is examined, the richer the values obtained. The harmony created in the process of transformation/acculturation is the thing that makes the Javanese culture rich with meanings. It is not only a blend of two different elements, but also has a dimension that is able to form a value in a harmonious process as it existed in various works of art of the Islamic Mataram that are part of the Javanese cultural pluralism as a whole.

Despite all the process of cultural transformation, in fact, mysticism and mythology of cultural syncretism are difficult to be separated from the Javanese people's lives. Thus any form of internalization of Javanese-Islamic culture should be recognized as a process that is not finished, and will continue to adapt to space and time. Therefore, we can still continue to develop the existing art and culture, as long as it is still functional and in harmony with the advances of times.

\section{BIBLIOGRAPHY}

Baried, Siti Baroroh, et.al., 1987., Panji: Citra Pahlawan Nusantara. Jakarta: Departemen Pendidikan dan Kebudayaan.

Dewan Ahli Yayasan Siswo Among Beksa., 1982. Kawruh Joged Mataram. Yogyakarta: Yayasan Siswo Agung Beksa.

Herkovits, M.J., 1938. Acculturations The Study of Contact, New York: Alred A.Koff.

Jamil Abdul, et.al., 2000. Islam \& Kebudayaan Jawa. Yogyakarta: Gama Media. Kayam, Umar., 1989. Transformasi Budaya Kita. Yogyakarta: Pidato Pengukuhan sebagai Guru Besar di Universitas Gadjah Mada.

------------., 1981. Seni Tradisi Masyarakat. Jakarta: Djaya Pirusa.

Koentjaraningrat., 1984. Kebudayaan Jawa. Jakarta : Balai Pustaka. 
Kunto Wijoyo, et.al., 1987. Tema Islam Dalam Pertunjukan Rakyat Jawa: Kajian Aspek Sosial Keagamaan dan Kesenian. Yogyakarta: Departemen Pendidikan dan Kebudayaan, Dirjen Kebudayaan, Proyek Penelitian dan Pengkajian Kebudayaan Nusantara Javanologi.

Maus Macsel., 1952. Resiprocity. London: Philip Wilson Publisher.

Ririn Sofwan, et.al., 2000. Islamisasi di Jawa. Yogyakarta; Pustaka Pelajar.

Sodarsono, et.al., 1989. Sultan Hameku Buwana IX Pengembang dan Pembaharu Tari Jawa Gaya Yogyakarta, Yogyakarta: Pemerintah Daerah Istimewa Yogyakarta.

----------., 2000. Masa Gemilang dan Memudar Wayang Wong Gaya Yogyakarta. Yogyakarta: Tarawang.

Shellabear W.G., 1976. Sejarah Melayu. Kuala Lumpur: Petaling Jaya.

Wibowo Fred (editor)., 1981. Mangenal Tari Klasik Gaya Yogyakarta, Yogyakarta: Dewan Kesenian Propinsi DIY dan Proyek Pengembangan Kesenian DIY, Departemen P dan K.

Wiroprmudjo, Kartidjo., 1980. "Wayang Golek Menak”, dalam Almanak Dewi Sri.

Woodward R. Mark., 1999. Islam Jawa : Kesalehan Normatif versus Kebatinan. Yogyakarta: LKiS. 